\title{
Entry mode choice in the international new ventures context. A study from different theoretical perspectives
}

\begin{abstract}
Few studies have investigated the factors that enhance entry mode choice in the context of international new ventures (INVs). In this paper, we hypothesize that the characteristics of INVs' products or services can explain their preference for equity entry modes. We also hypothesize that the inter-firm networks in which INVs are embedded play a deciding role in their choice of non-equity entry modes. When INVs are in inter-firm networks in which activities are developed to manage them, non-equity entry modes are preferred. We have adopted an effectuation approach to study the influence of different inter-firm network management activities on entry mode choice. In short, we have studied the effect of developing inter-firm network knowledge exchange, coordination, adaptation, conflict resolution and resource sharing management activities. In this paper we attempt to contribute to international entrepreneurship studies by reconciling the most widely accepted approaches to entry mode choice (Transactional Cost Economics, Organizational Capabilitiesbased and Network perspective) and international new ventures. Our findings show that the technological complexity of INVs' products/services explain their preference for equity entry modes. Additionally, the development of network management activities among the networked firms determines the INVs' preference for non-equity entry modes. Our results draw a decision model that differs from the ones derived from previous perspectives, which highlight the role of different characteristics of international new ventures.
\end{abstract}

\section{Keywords}

Entry mode. International new venture. Networking.

\section{Introduction}

The phenomenon of international new ventures (INVs) has attracted major interest within the field of international entrepreneurship (IE) (Oviatt and McDougal 2005). INVs are new ventures that internationalize from the very outset (Oviatt and McDougal 1994), and consequently they usually face important market legitimacy hurdles associated to their youthfulness and early international activity (Wood et al. 2011). IE research suggests that the appropriate choice of entry mode can reduce INVs' liability of newness and foreignness (Chen 2006), thus contributing significantly to their market legitimacy (Wood et al. 2011) and corporate growth (Gabrielsson et al. 2008) in foreign markets during their childhood. Entry mode refers to the organizational arrangements employed to sell in foreign markets (Anderson and Gatignon 1986). IE literature also suggests that INVs use a wide variety of foreign entry modes (Gabrielsson et al. 2008) ranging from non-equity entry modes (NEEMs) (Oviatt and McDougall 1994; Jansson and Sandberg 2008; Gabrielsson et al. 2008) to equity entry modes (EEMs) (Burgel and Murray 2000; Aspelund et al. 2007; Ripollés et al. 2012). However, IE research 
does not provide a comprehensive theoretical model to assist INVs' entrepreneurs in choosing between NEEMs and EEMs. From our point of view, this is an important gap in the literature.

The choice of entry modes "is too complex and too broad in scope to be accommodated by any one model or any one perspective" (Coviello and Jones 2004, p. 497), thus a holistic approach is preferred (Crick and Jones 2000; Coviello and Jones 2004; Crick and Spence 2005). Following this tradition, our research borrows some of the lines of argument from the most widely accepted perspectives on entry mode choice (Transaction Cost Economics (TCE), Organizational Capability (OC) and Network perspective), and we reconcile the theoretical developments presented above and of international new ventures. The generalizability of theory is important, but given the characteristics of INVs (limited market legitimacy, selling complex technology-based products/services, offering after-sales service and being networked firms), it is important to reflect on the boundary conditions of existing theory and to examine potential sources of variation (Jones et al. 2011). Thus, we develop arguments to show how these characteristics influence INVs' entry mode choice. In developing and testing our model, we make several contributions to the literature. First, this study extends previous IE research mainly focused on the factors that can promote early international entry (Gil-Pechuan et al. 2013; Baronchelli and Cassia 2014) to include insights on the factors that can promote EEM and NEEM choice in the INV context. Gaining additional insight into this choice will ease comparisons with gradualist approaches (Jones and Coviello 2005) or other internationalization pathways (Aspelund et al. 2007), thereby enabling us to better understand the INVs' process of internationalization from a strategic point of view.

Second, little empirical evidence exists on the processes in which inter-firm networks produce outcomes in terms of business growth ( $\mathrm{Ng}$ and Rieple 2014), hence our study contributes to this incipient research line by studying the role of inter-firm networks in entry mode choice. To do so we adopt an effectuation perspective to study network management, which allows us to highlight the influence of different network management activities: knowledge exchange, coordination, adaptation, conflict resolution and resource sharing. Thus, we complement past IE research on inter-firm networks and entry mode choice, which has mainly focused on the structural characteristics of inter-firm network ties and on the overall inter-firm network structure (Coviello and Munro 1997; Berg et al. 2008).

And finally, our research also has important implications for practitioners. Identifying the factors influencing entry mode choice may help prepare firms for the dangers of different entry modes, and more positively assist in the generation of new resources leading to innovative internationalization pathways and the continuance of rapid international growth.

This paper is organized as follows. After the introduction, we present a theoretical discussion of the results of previous research studies regarding entry modes and INVs. Next, we discuss the effects of different factors on EEM and on NEEM 
choice in the INV context. Subsequently, we explain the study methodology and present and analyse the survey data. Finally, we discuss the findings and limitations of our study and suggest directions for further research.

\section{Entry Modes and INVs from the Transaction Cost Economies and the Organizational Capabilities-based} perspectives

Choice of entry mode is an important strategic decision for INVs, as it involves a given level of resource commitments in different target markets with different levels of risk, control and profit return. As suggested by Kumar and Subramanian (1997), there is a natural hierarchy among the various modes of entry according to different degrees of resource commitment in foreign markets ranging from NEEMs (for this research, exporting through intermediaries or licensing) to EEMs (for this research, subsidiaries and joint-ventures). Evidence certainly shows that INVs use different entry modes (Sasi and Arenius 2008) and that as INVs lack tangible resources, the choice of entry modes cannot be principally based on these resources. It is more reasonable to suppose that this choice may be based on the capacity of INVs to leverage a collection of intangible resources (Gleason and Wiggenhorn 2007). For Burgel and Murray (2000), INVs choose entry modes based not only on their available resources, but also on the specific local demands for customization, support, etc. (Burgel and Murray 2000; Melén and Rovira 2009). The study of the different entry modes has caught the attention of researchers from various scientific traditions, some of which are of particular interest in this research, namely, the TCE, the OC or the Network Tradition. These approaches coincide in considering that the transfer of intangible resources is the key variable in explaining entry mode choice.

TCE has led researchers to propose transaction-related variables as determinants of the most efficient governance mode: the value of contributed assets and the tacit nature of transferred know-how. These variables reflect the dissemination risk that firms face in new markets (Erramilli and Rao 1993; Gatignon and Anderson 1988; Madhok 1998). Dissemination risk refers to the risk that a firm's specific advantages might be expropriated by a partner (Madhok 1998). Negotiations for collaboration demand open communication and evidence of knowledge, yet at the same time there is a major risk of losing strategic knowledge (Davenport et al. 1999; Pett and Dibrell 2001). Firms are expected to choose the governance or entry mode that minimizes the costs of carrying out particular transactions (Williamson 1985).

INVs are characterized by usually selling unique and self-developed technology-based products/services (Burgel and Murray 2000; Gabrielsson et al. 2008). During the sales process for these products/services, the vendor may be required to spend considerable time advising and educating potential customers on the key merits of the product/service (Burgel and Murray 2000). After the sale, technologically more complex and unique products/services may require installation by trained staff, regular after-sales service, and periodic upgrades (Burgel and Murray 2000). This pre- and post-sale service is an important competitive factor for INVs (Knight and Cavusgil 2004). The transfer of this knowledge to a 
partner represents a significant dissemination risk for an INV (Zacharakis 1997; Coviello and Munro 1997), because such tacit knowledge is difficult to protect through patents or other legal formulas (Williamson 1985). Moreover, INVs' lack of experience in cooperation makes it difficult to understand, predict or articulate all the contingencies that may arise in NEEM contracts (Blomqvist et al. 2008) through the design of almost "complete" contracts (Williamson 1985; SolisRodriguez and Gonzalez-Diaz 2012). Even if INVs could anticipate these contingencies to introduce clauses in contracts to minimize moral hazard concerns (Argyres and Mayer 2007), their weak negotiating capacity would limit the effectiveness of those clauses. Consequently, according to TCE logic opportunism seems to be an important challenge associated to NEEMs for INVS, and suggests the INVs' need to offer after-sales service and/or technological support will have a positive influence on the choice of EEMs, while this influence will be negative on the choice of NEEMs.

H1a: The international new ventures' need to offer after-sales service has a positive influence on their choice of equity entry modes.

H1b: The international new ventures' need to offer after-sales service has a negative influence on their choice of non-equity entry modes.

The OC perspective maintains that the basis for internationalization must be sought in the firm's pool of resources and capabilities (Madhok 1997; Teece et al. 1997). The OC perspective argues that the driving force underlying firms' entry mode decisions may be the management of a firm's capabilities in terms of development and deployment of its knowledge base. This perspective broadens the focus from minimizing the (transaction) costs involved in organizing an activity under a particular governance arrangement to also incorporating the management of value erosion and enhancement, inherent in a firm's knowledge base. In addition to the effects on an INV's pool of resources and capabilities due to possible opportunistic behaviour from its partners, inadequate capabilities in partner firms could also erode the firm's resources and capabilities. When firms have invested in idiosyncratic know-how, the know-how has more value for the firm than for the potential collaborator/licensee (Madhok 1997). In this situation, firms will prefer entry modes that imply equity investment due to the limitations of possible partners over efficiently and effectively acquiring and integrating this particular knowledge into its own functioning.

The commercialization of complex technological products/services (Gabrielsson et al. 2008) requires a high degree of asset specificity (Burgel and Murray 2000). INVs would therefore need to find partners willing to make specific investments to guarantee the efficient and effective marketing of their products/services, but the size and novelty of their proposals may prevent them from finding such partners. Consequently, according to OC logic the technological complexity of INVs' products/services will have a positive influence on the choice of EMM and a negative one on the choice of NEEM. Thus, in this paper we suggest that: 
H2a: The technological complexity of international new ventures' products/services has a positive influence on their choice of equity entry modes.

H2b: The technological complexity of international new ventures' products/services has a negative influence on their choice of non-equity entry modes.

\section{More than a structure: The influence of inter-firm network management activities}

The network approach can be viewed as an alternative perspective that is especially appropriate for explaining NEEMs in the INV context (Coviello and Munro 1997; Berg et al. 2008). For the purposes of this paper, an inter-firm network consists of direct dyadic, informal ties and the relationships between these ties, with the firm at the centre of the interfirm network as the focal actor (Hite and Hesterly 2001). Informal ties comprise relationships defined as implicit, personal, generic, and not governed by any legal agreements (Rank 2008). To study the role of networks on entry mode choice we focus on management activities and not on the structural characteristics of network ties. The reason underlying this procedure is that what determines network benefits for firms is not only the fact of belonging to a certain type of network - as the structural studies suggest - but rather their ability to manage interactions (Brüderl and Preisendörfe 1998).

Literature shows that there are two possibilities to manage networks (Ritter et al. 2002; 2004). One of them is management through the development of different management tasks such as planning, organizing, staffing and controlling. In this situation, a firm is able to choose its partners and to control and direct the way the relationships operate (Ritter et al. 2002; 2004). The main argument for network management tasks is the need to integrate the contributions from different actors in the network in order to develop common benefits (Ritter et al. 2004). A causation approach to studying network management seems to support Ritter et al.'s $(2002 ; 2004)$ research. Put simply, entrepreneurs using causation logic have a predetermined goal and select resources to attain these goals (Sarasvathy 2001). Causation is consistent with rational decision-making models or deliberate strategy approaches (Ansoff 1988; Quinn et al. 1988).

On the other hand, effectuation logic can also be possible (Sarasvathy 2001; Sarasvathy and Dew 2003). Effectuation logic is consistent with emergent or non-deliberate strategy-making processes (Quinn et al. 1988). Effectuation scholars introduce the notion of effectual networks, which are composed of such relationships that "do not have the luxury of drawing upon existing networks of trust and/or clear specifications of profit opportunities" (Sarasvathy and Dew 2003, p. 4). Instead of having a specific goal to drive their partner selection, entrepreneurs network with all interested actors to increase their means for opportunity discovery (Galkina and Chetty 2015). The non-predictive nature of effectual networks provides an opportunity to present several implications with regard to their management: effectual networks are unmanageable, in the sense of being controlled and directed by a single participant firm. The effectual network cannot be 
fully coordinated/managed by a single actor, and management of network relations takes the form of coordinated management activities among the firms (Sarasvathy and Dew 2005; Galkina and Chetty 2015). All the firms in the network need to be involved in its management. Effectuation as a characteristic of network management exists as a matter of degree, rather than a category diametrically opposed to causation (Galkina and Chetty 2015). Galkina and Chetty (2015) point out that, although effectuation is not positioned as a "better" logic of reasoning, it is being more applicable than causation to explain network management, especially in IE research (Sarasvathy et al. 2014). INVs' limited resources and market power hinder their ability to play a leading role in managing their networks. INVs have to cope with managing interactions taking place in multiple relationships, which may be with partners not entirely of their choosing. Each network partner has a history, even though different objectives may exert an influence on how things are done.

In this context, we have identified five inter-firm network management activities (INMA): knowledge sharing, adaptation, coordination, conflict resolution, and resource availability, which can influence NEEM choice. Inter-firm knowledge sharing activities are defined as the set of activities that are performed jointly by firms in the network, enabling them to obtain market information. Effective knowledge-sharing routines are designed not only "to exchange market information but to make available their knowledge and other operant resources and to create new knowledge or new operant resources" (Gummesson and Mele, 2010: p. 191). In networks where this dialogue is established, member firms can "get insight in what the parties can do together and for the other through access to a common meaning or shared field of knowledge" (Grönroos 2004, p. 159). This dialogue involves firms in the network committing to exchange information to enable immediate reactions to new market demands, to develop a conjoint learning on market demands, to exchange knowledge to improve their offerings and to jointly develop solutions for new market demands (Helfert et al. 2002).

Inter-firm network coordination refers to synchronization of partners' actions (Mohr and Nevin 1990). Network coordination can be seen as routines for integrating network activities (Löfgren et al. 2008). IMP project studies show that relationships usually involve a number of managers who work together to coordinate their firms' activities and create interrelated routines (Cunningham and Homse 1986). This coordination also comprises the establishment, use and control of formal rules and procedures and the exertion of informal influence (Helfert et al. 2002).

Inter-firm adaptation refers to the activities firms must adopt to meet partners' special needs or the ability to adapt to new circumstances (Helfert et al. 2002). Harrigan (1988) showed that partnerships are more likely to succeed when partners possess complimentary missions and resource capabilities. Adaptation processes include relationship-specific investments in areas such as technology, products/services, manufacturing processes, logistics, administration, employee qualification or financing (Hallén et al. 1991; Claycomb and Frankwick 2010). 
The use of inter-firm constructive conflict resolution mechanisms extends the notion of coordination because these mechanisms address extraordinary, non-standard situations, which are bound to occur in every long-term relationship (Ruekert and Walker 1987). Interaction/network theory states that organizations linked by cooperative interaction processes employ other non-contractual processes associated with conflict, coexistence, collusion and competition (McLoughlin and Horan 2002). In relationships characterized by a desire to establish and maintain long-term, collaborative efforts, managers favour productive conflict resolution mechanisms because they are less volatile. Constructive mechanisms contribute to a relationship, strengthen each firm's identification with the other, and increase cooperation. Firms developing long-term, collaborative relationships engage in joint problem-solving because integration satisfies more fully the needs and concerns of both parties (Claycomb and Frankwick 2010). Joint problem-solving to resolve conflict leads to mutually satisfactory solutions, thereby enhancing relationship success (Mohr and Spekman 1994). Constructive conflict resolution requires a timely reaction to conflict, a readiness to compromise and a sense of justice. Establishing routines to facilitate the inter-firm exchange of resources other than information and knowledge is the final dimension in our INMA construct.

INVs consider two possible situations related to the choice of NEEMs: (1) potential partners form part of the INV's network, and (2) potential partners do not form part of its network of contacts. In the first of these two situations, INMA can help to provide INVs with information on the capacity and suitability of potential network partners for establishing NEEMs. Moreover, the climate of trust, collaboration, commitment and engaging in INMA may reduce the risks of opportunism associated to the characteristics of INVs' products/services.

Focusing on the second of these scenarios, the effective knowledge-sharing activities that define the INMA construct facilitate information exchange among the network members, broadening the information base available to INVs and thereby helping INVs to identify suitable NEEM partners. But INMA are more than a series of information-sharing routines; by developing routines to effectively adapt, coordinate, resolve conflicts and share resources, firms in a network create a stable collaborative environment that enables INVs not only to identify potential NEEM partners but also to obtain information on their suitability and honesty. Additionally, the INV must convince potential partners that collaboration will bring mutual benefits, despite the major drawback of the INV's lack of legitimacy in the market. INVs are new companies that can only offer business projects which are based on a series of conjectures made by the business owners regarding the future viability of their business ideas in different foreign markets (Eckhardt and Shane 2003). Business owners cannot be certain that their business opportunities will be profitable in foreign markets. In this context, potential NEEM partners will positively assess references from INVs' network members that are in favour of the INV project (Berg et al. 2008). Through INMA INVs can use their network partners as a calling card. The role of networks as 
an appropriate strategy to gain market legitimacy for new ventures is well documented in the literature (Almobaireek et al. 2016). Consequently, in both scenarios, INMA alleviate the risk associated with the formation of NEEM agreements and help increase a firm's willingness to form NEEM agreements. Transacting with firms about which information is available is less risky than transacting with firms whose collaborative behaviour is unknown (Al-Laham et al. 2008).

The development of INMA will also contribute to gain relational experience that INVs will use if they establish NEEM contracts. Experiences typified in this way form the interpretive basis for future situations (Dyer and Singh 1998; Fink et al. 2008). When INVs have engaged in prior cooperative activities, they can use this relational experience in new cooperative agreements, thus helping to prevent them from having potential problems with new partners. Moreover, when NEEM partners belong to INVs' networks, the development of INMA among them provides an important relational background. This relational experience can help INVs to anticipate possible partners' opportunistic behaviours and can be very useful in selecting trustful NEEM partners. This relational experience is also useful when NEEM partners do not belong to the INVs' inter-firm network of contacts. In this case, INVs do not have previous experience in cooperation with NEEM partners that enable them to be able to efficiently design the steps with which the aims of NEEMs are fulfilled. In this case, INVs can use their relational experience to build up norms that specify permissible behavioural limits in new cooperative agreements (Dyer and Singh 1998), thereby contributing to diminish the risks associated with dissemination. Thus, the development of INMA among network members can positively influence the choice of NEEMs.

NEEMs also have the disadvantage of not providing effective control over the promotion of their products or sales operations in local markets, thus compromising the overall effectiveness of the market penetration strategy. Aspelund, Madsen and Moen (2007) report reduced learning as another important disadvantage associated with the use of NEEMs that may deteriorate INVs' performance. But it seems logical to assume that the intelligence generation and dissemination, coordination, conflict resolution and adaptation processes associated with the development of INMA among the members of the INVs' network will help these firms to develop knowledge and promote learning, and thus compensate for any reduced market learning associated to the use of NEEMs.

Consequently, although INVs sell unique and complex technological products/services, the development of INMAs will positively influence the NEEM choice. Moreover, the development of INMAs is not a costless activity. INVs need time and resources to develop activities of coordination, of adaptation or of interchange of resources among network members. The need for these resources will limit the INVs' capabilities to make administrative, marketing and organizational investments associated with EEMs, and thus a negative relation could be expected between the development of INMAs and the choice of EEM. Consequently: 
H3a: Inter-firm network management activities positively influence international new ventures' choice of nonequity entry modes.

H3b: Inter-firm network management activities have a negative influence on international new ventures' choice of equity entry modes.

\section{Methodology}

To test these hypotheses, data were gathered from a sample of Spanish international ventures that operate in several industries. Firms were selected from the Dun \& Bradstreet 2010 Database. Following most studies on INVs (Coviello and Jones 2004; Knight and Cavusgil 2004), four criteria were used to select the companies for this survey. First, the companies had to be new ventures. The length of time that is permitted for a firm to be classified as "new" varies from three to ten years (Madsen and Servais 1997; Milanov and Fernhaber 2009). Following previous studies (McDougall and Robinson 1990), we established a threshold of less than five years to define new ventures. Second, the companies had to be engaged in international activities. Recently, a threshold of over $25 \%$ of annual sales has been established (Jones et al. 2011) for this purpose. Thus we eliminated firms with isolated activities abroad, as other studies have already done (Jantunen et al. 2008; Milanov and Fernhaber 2009). Third, companies had to belong to a network. In this research we assume that network interactions arise from more than the two-sided matching process considered in traditional IE research. These webs of connected relationships are labelled networks (Johanson and Vahlne 2009). For our purposes, a network involves at least three independent companies who all maintain economic or social relationships and voluntarily share knowledge and experiences with the other companies and know about their activities inside the network. In the minimum form of a network, company A has economic or social relationships with companies $\mathrm{B}$ and $\mathrm{C}$ and knows that $\mathrm{B}$ and $\mathrm{C}$ have economic or social relationships with each other; furthermore, $\mathrm{B}$ and $\mathrm{C}$ each know that the other has an economic or social relationship with A (a self-report from INV managers warranted these requirements). Finally, in agreement with other studies on new ventures (Robinson and McDougall 2001), firms could not be subsidiaries or affiliated companies. Our sample included only independently owned and operated new ventures. This process yielded a total population of 2019 INVs. The field research was conducted during the second quarter of 2010, and the final sample consisted of the 200 INVs that responded to the questionnaire (a 9.95\% response rate).

For the field research, interviewee collaboration and confirmation of the e-mail address were requested. After the questionnaire had been sent, follow-up contact was made by telephone to increase the response rate. The questionnaire was posted on the Internet, and an e-mail with a link to the questionnaire was sent to each manager. Table 1 summarizes the main descriptive characteristics of the sample.

[Insert Table 1] 
Responses from early and late respondents were compared to test for non-response bias. T-test analysis indicated that there were no significant differences (at the $\mathrm{p}<0.05$ level), thereby indicating absence of non-response bias (Armstrong and Overton 1977).

\subsection{Measuring Instruments}

\subsubsection{Independent variables}

The need for after-sales service in foreign markets was measured by the managers from 1 (none at all) to 5 (a lot). Additionally, managers were asked how technologically complex their products were on a scale from 1 (not at all) to 5 (very complex) compared with those of their competitors. Following Grunert, Fruensgaard, Risom, Sonne, Hansen and Trondsen's (2002) procedure, an adaptation of the scale proposed by Helfert, Ritter and Walter (2002) was used for measuring INMAs (Table 2).

[Insert Table 2]

\subsubsection{Dependent variable}

We conceptualized NEEMs as exporting through intermediaries and licensing, while foreign direct investments, such as subsidiaries and joint-ventures were considered EEMs. According to this classification, interviewees were asked the number of times their companies had entered a new international market in three risk areas using equity and NEEMs. Following previous research (Rasheed 2005), this study uses data from the "International Country Risk Guide” (ICRG), a monthly newsletter that quantifies a risk rating using factors consistent with the determinants of risk identified in previous academic research (Cosset and Roy 1991), to define the three risk areas considered.

\subsubsection{Control variables}

The main aim of our research is to analyse the effects of INVs' after-sales service in foreign markets, technological complexity of INVs' products and INMA on equity and non-equity entry modes choices. Nevertheless, additional predictors pointed out by the literature were also tested. According to the Stage perspective, firm size and international experience are crucial predictors of subsequent firm international actions (Oakey et al. 1988).

INVs' size was measured using the number of employees. We measured international experience as the number of years the firm has already been engaged in international operations (Burgel and Murray 2000). Finally, firms' experience was measured using the age of the INVs.

\subsubsection{Validity and Reliability of the Scales.}


Cause indicators are more appropriate when an indicator can be viewed as causing rather than being caused by the latent variable measured by the indicators (MacCallum and Browne 1993). The entry mode measurements proposed in this article have the above characteristic.

Four issues are critical for successful index construction (Diamantopoulos and Winklhofer 2001): content specification, indicator specification, indicator collinearity and external validity. To ensure the content and indicator specification of our indexes, all the items were taken from a review of the related literature. Furthermore, we attempted to ensure that the indexes met the conceptual definition and reflected all the relevant dimensions. Multicollinearity analyses of indicators in the different indexes indicated that the maximum variance inflation in each index (2.690 in EEMs and 1.578 in NEEMs) was far less than the common cut-off threshold of 10 (Kleinbaum et al. 1988). Finally, following the recommendations of Jarvis, Mackenzie and Podsakoff (2003) for the assessment of external validity, two reflective indicators (access to market and global satisfaction) were considered in the formative construct, and a multi-indicator, multi-cause model was estimated for the index. Table 3 presents the reflective indicators and estimates of the models.

[Insert Table 3]

In relation to the INMA construct, social researchers usually use confirmatory analysis to evaluate the convergent validity of reflective measures. Because the aim of our analysis is to describe the validity of indicators as measurement instruments of this scale, the different initial model was adjusted following the indications of Jöreskog and Sörbom (1993). The following criteria were applied: each indicator had to attain a lambda value of 0.5 to ensure its continuity on the scale, and the $t$ value had to be significant. Following these criteria, the item KONWSHA3 was eliminated from the scale. The validity analysis results demonstrated that all the parameters had a high lambda $(0.63-0.93)$, all the $t$ values were significant at $\mathrm{p}=0.001$, and the fit indexes considered jointly were good $\left(\chi^{2} / \mathrm{df}=2.136, \mathrm{RMSR}=0.048, \mathrm{GFI}=0.91, \mathrm{NFI}\right.$ $=0.97, \mathrm{CFI}=0.98, \mathrm{IFI}=0.98)$. Although the ratio of chi-square to its degree of freedom was greater than 2 , this index is not very reliable (Hayduk 1987; Wheaton 1987). There is no consensus regarding an acceptable ratio for this statistic, recommendations range from as high as 5.0 (Wheaton et al. 1977) to as low as 2.0 (Tabachnick and Fidell 2007). Additionally, researchers usually combine it with other goodness-of-fit measures (Hair et al. 1998). Thus considered jointly, the indexes show good overall fits. The scale also presented a good index of reliability $(\alpha=0.899, \mathrm{CR}=0.97, \mathrm{EV}$ $=0.688)$.

Discriminant validity between the scales was tested with the confidence interval (Anderson and Gerbing 1988) and the extracted variance (Fornell and Larker 1981). According to the confidence interval test, the value "1" should not appear in the confidence interval of the correlations between the scales in the same level of analysis. According to the extracted variance test, to indicate discriminant validity, the extracted variance for each construct should be greater than the squared 
correlation between that construct and any other construct. Table 4 presents the results of this test, which were satisfactory in all cases.

[Insert Table 4]

\section{Results}

Structural equation models (SEMs) have proved to be particularly useful when the research aim is to establish the direct causal contribution of one variable to another in a non-experimental situation (Jöreskog and Sörbom 1993). This approach also allows the simultaneous estimation of both the measurement equations and the structural equations (Carmines and McIver 1981). Consequently, it enables us to compare the effects of several antecedents of entry modes while considering the country risk of the entry and the dimensionality of the management activities in the inter-firm network in the measurement model.

To test our hypotheses, we included in our model alternative possible predictors as drivers of the decision to choose an equity or non-equity entry mode. Hence, we contrast two models with one stating the relations between the predictors and EEMs and the other stating the relations between the same predictors and NEEMs. To simplify the models, the INMA measurement scale was narrowed down to five indicators (corresponding to its dimensions) by averaging the items in each dimension. Several modification indexes suggested that the models could be improved, so we reran the models on the calibration sample and reviewed the modification indexes. Descriptive statistics are presented in Table 5, and Table 6 shows the results of the estimation of the relationship model with SEM. Considering all of the indexes conjointly, the model fits the data quite well.

[Insert Table 5 about here]

[Insert Table 6 about here]

The results of estimating the relationship model with SEM indicate that after-sales service does not show a significant relationship with EEMs or NEEMs $(\Delta=0.04, \mathrm{t}=1.68$ and $\Delta=0.05, \mathrm{t}=1.25$, respectively). Consequently, our hypothesis H1a is rejected: the INVs' need to offer after-sales service does not positively influence their preference for EEMs. The results do not seem to support hypothesis H1b either. Additionally, our results suggest that the technological complexity of INVs' products/services have a significant effect on EEM choice $(\Delta=0.05, \mathrm{t}=2.86, \mathrm{p}<0.01)$, and do not seem to contribute in any way to the choice of NEEMs $(\Delta=-0.07, \mathrm{t}=-1.82)$, which lends support to our hypothesis $\mathrm{H} 2 \mathrm{a}$ but not H2b. That is, the INVs' need to make specific investments positively influences the INVs' preference for EEMs. The results also show a positive significant relation between INMA and NEEMs $(\Delta=0.79, \mathrm{t}=9.29, \mathrm{p}<0.001)$, while the relation with EEMs, also strong and significant, exhibits a negative sign, thus suggesting an inverse effect of those activities on the choice of these entry modes $(\Delta=-0.76, \mathrm{t}=-8.88, \mathrm{p}<0.001)$ and revealing the potential effect of INVs' 
INMA on the choice of entry into foreign markets through partnership. Thus, our hypotheses $\mathrm{H} 3 \mathrm{a}$ and $\mathrm{H} 3 \mathrm{~b}$ are also supported.

Analysis of the effects of the control variables performed independently suggests that they act differently on each type of entry mode. While firm size fosters the choice of NEEMs $(\Delta=0.21, \mathrm{t}=3.51, \mathrm{p}<0.001)$, it discourages the choice of EEMs $(\Delta=-0.11, \mathrm{t}=-4.46, \mathrm{p}<0.001)$. Similarly, while INVs' international experience and business experience have significant effects on the choice of EEMs $(\Delta=-0.21, \mathrm{t}=-3.30, \mathrm{p}<0.001 ; \Delta=0.20, \mathrm{t}=3.76, \mathrm{p}<0.001$; respectively), they do not seem to contribute in any way to the choice of NEEMs $(\Delta=-0.01, \mathrm{t}=-0.12 ; \Delta=-0.10, \mathrm{t}=-1.49 ;$ respectively).

\section{Discussion}

In this work, we have analysed some factors that influence INVs' choice of entry mode. Inspired by the TCE and OC perspectives, we have analysed the after-sales service and the technological uniqueness of products/services. Our findings have led us to reject the influence of after-sales service and/or technological support on EEM. These findings are in keeping with Burgel and Murray (2000), but run contrary to the results reported by Aspelund, Madsen and Moen (2007) and Ripollés, Blesa and Monferrer (2012) confirming the importance of marketing capabilities in INVs' EEM choice. Nevertheless, from our research we can accept the influence of product/technological uniqueness on EEM choice. But this is not the case of INMA, which has positive effects on NEEMs but negative on EEMs. Thus, our results seem to point out that traditional internationalization theories (TCE and/or OC) only explain INVs' entry mode choice when these firms do not develop INMAs. When INMAs are present, then INVs prefer NEEMs. We have extended past research by showing how INVs protect themselves against the problems associated to NEEM choice. We explain this result on the basis of the specificities of entry mode choice in the INV context: NEEMs are threatened by significant dissemination risks, and the benefits and the relational experience derived from the development of inter-firm network management activities is a valuable asset that INVs use in their NEEM choice. In general, our results are in keeping with other studies that question the suitability of traditional theories for explaining INVs' entry mode choice and call for alternative theoretical perspectives (see, for example, Jones et al. 2011).

Our findings are in line with other authors, like Hagen and Zucchella (2014), and suggest that cohesive networks play a more important role than large networks in entry mode choice (Coviello and Munro 1997; Berg et al. 2008). But they extend past research by showing that the point is not to belong to a certain type of network but the firm's ability to manage interactions. These findings contribute to the literature on firms' network management (Ritter et al. 2002; 2004; Ritter and Gemünden 2003) by showing the importance for INVs of developing inter-firm network management activities which do not necessarily respond to a strategy planned by top management. This situation has not been specifically contemplated by authors before, but it does reflect the reality in most INVs (Sarasvathy et al. 2014; Galkina and Chetty 
2015). In line with Nummela et al. (2014), Sarasvathy et al. (2014) or Galkina and Chetty (2015), our results suggest that at least in the initial stages of INVs' lives, the effectuation approach to network management may be more appropriate than the causation approach. We thus contribute to a very embryonic stream in effectuation research that explores effectuation principles in an internationalization context (Sarasvathy et al. 2014; Galkina and Chetty 2015). We did so by showing how INVs' entrepreneurs use and expand the 'who I know' (inter-firm networks) aspect of the means they employ in entry mode choice.

\section{Concluding Remarks}

Our conclusions highlight the idea that INMAs can be considered a key aspect in INVs' NEEM choice and that the technological complexity of INVs' products/services influences their EEM choice. Moreover, the results seem to demonstrate that alternative factors like after-sales service do not appear to contribute to INVs' choice of NEEs. This study therefore reinforces the idea that knowledge obtained in other contexts (e.g. in small and medium-sized enterprises) cannot simply be transferred (Oviatt and McDougal 1994).

Our work has several practical implications. Entrepreneurs in INVs face the challenge of managing multiple NEEMs. Partner selection must be considered a key determinant of NEEMs choice. The literature on alliances offers little guidance on this challenge in the small business context. There is literature about the characteristics of an ideal partner (Lu and Beamish 2001; Gabrielsson et al. 2008) but not about how firms suffering from the liabilities of newness and foreignness can meet that ideal partner. Our work suggests that INVs' networks are important for locating partners and establishing NEEMs arrangements with them. More importantly, from the applied perspective, our results suggest that INV entrepreneurs need to engage in the subtle and difficult task of establishing routines that enable them to develop interfirm network management activities in coordination with other firms. Therefore, the findings of this study should encourage INVs' owners to consider the importance of not only belonging to networks but also being able to establish coordinated management processes, like the one proposed in this paper.

Equally important, INMAs can help diminish any conflicts that might arise when NEEM contracts are in place. More specifically, INVs' entrepreneurs can expect to generate networking capabilities through the coordinated management activities carried out between INVs and their partners. Furthermore, INVs' entrepreneurs should cautiously become involved in promoting INMAs among the firms in their networks. Finally, the results of our study sound a cautionary note about overstating the performance benefits of network participation and suggest it may be advisable to become involved in co-management activities with firms in their inter-firm networks. 
Our research has several empirical and conceptual limitations. From an empirical perspective, opting only for INVs in Spain limits any generalization of the results to other international contexts. New studies could therefore examine the relations proposed in other contexts to test the results reported here. Similarly, our proposed model, based on a multisector sample, can serve as a reference for other studies to focus on specific sectors and industries.

Our empirical study is based on the responses of a single interviewee for each company and network in our sample, thereby raising three issues. First, there is the question of whether a single interviewee can respond adequately for an entire organization. Second, our survey was aimed at entrepreneurs of a single company, who responded regarding the operation of inter-firm relationships as a whole. Third, the fact that the fieldwork took place through an online questionnaire casts doubts about who really answered the questionnaire.

The use of cross-sectional data in this research can be considered a limitation when making causal inferences. Future studies should therefore examine the relationships proposed here using longitudinal data and a combination of positivist and interpretative methods, such as the ethnographic or phenomenological method (Coviello and Jones 2004). Furthermore, qualitative research into the issues addressed in this study would benefit from interpretation of the measurements proposed here. The opinions and perceptions of different members in the same network concerning the operation of INMAs could be included to obtain contrasting responses, which would more accurately represent the real inter-firm experience. Similarly, in relation to the other factors that reflect a firm's general behaviours, qualitative studies would provide responses from employees at different hierarchical levels, in agreement with the suggestions in works such as those by Schlosser and McNaughton (2009).

From a conceptual point of view, the study of INMAs reflects our own biases and research preferences, and there may well be other inter-firm tasks that do not fall under our purview but still influence non-investment entry mode choice in INVs.

Future research might also explore the role of INMAs in the development of INVs' inter-firm networking capabilities. Fernhaber and McDougall (2005) have noted the importance not only of participating in networks but also of developing network management capabilities. Our findings encourage us to consider INMAs when analysing a firm's network management capability because they focus on non-deliberate aspects of network management. Recently, Laurell et al. (2015) explored how and when the individual key actors' combined networking activities develop critical capabilities during different phases of an INV's early development but, to the best of our knowledge, there are few studies of the factors that can contribute to the development of INVs' network management capabilities and their implications. Given that INMAs help to create routines in INVs that facilitate cooperation between the firms in their networks, INMAs should 
positively influence the generation of network management capabilities. The importance of our proposal is justified by the influence of INMAs on entry mode choice.

Additionally, future research might evaluate the dynamics of non-equity formation and the role of INMAs in that process. To sustain their growth, INVs may find the need to establish NEEM contracts with different partners. It is logical to think that INVs should simultaneously develop different types of non-equity arrangements. Managing a portfolio of NEEMs entails appreciating any potential conflict or overlap between different NEEM partners (e.g. partners in the same country) and determining the timing of terminating on-going NEEMs and initiating new ones (Al-Laham et al. 2008). Authors such as Hagen and Zucchella (2014) have concluded that timeliness of network development in accordance with the given growth strategy is an essential component of network value. INMAs can contribute to managing portfolio dynamics, such as the sequence of initiating, processing and terminating NEEMs over time, and can therefore contribute to INVs' growth.

\section{References}

Al-Laham, A., Amburgey, T., \& Bates, K. (2008). The Dynamics of Research Alliances: Examining the Effect of Alliance Experience and Partner Characteristics on the Speed of Alliance Entry in the Biotech Industry. British Journal of Management, 19, 343-364.

Almobaireek, W. N., Alshumaimeri, A. A., \& Manolova, T. S. (2016). Building entrepreneurial inter-firm networks in an emerging economy: the role of cognitive legitimacy. International Entrepreneurship and Management Journal, 12(1), 87-114.

Anderson, E., \& Gatignon, H. (1986). Modes of Foreign Entry: a Transaction Cost Analysis and Propositions. Journal of International Business Studies, 17(3), 1-26.

Anderson, J.C., \& Gerbing, D.W. (1988). Structural Equation Modelling in Practice: a Review and Recommended Twostep Approach. Psychological Bulletin, 103(3), 411-423.

Ansoff, H. I. (1988). Corporate Strategy. London: Penguin Books.

Argyres, N., \& Mayer, K. J. (2007). Contract design as a firm capability: An integration of learning and transaction cost perspectives. Academy of Management Review, 32(4), 1060-1077.

Armstrong, J.S., \& Overton, T.S (1977). Estimating Nonresponse Bias in Mail Surveys. Journal of Marketing Research, 14(3), 396-402.

Aspelund, A., Madsen, T.K., \& Moen, O. (2007). A Review of the Foundation, International Marketing Strategies, and Performance of International New Ventures. European Journal of Marketing, 41(11/12), 1423-1448. 
Baronchelli, G., \& Cassia, F. (2014). Exploring the antecedents of born-global companies' international development. International Entrepreneurship and Management Journal, 10(1), 67-79.

Berg, M.S., Aspelund, A., \& Sørheim, R. (2008). The Hybrid Structures of International New Ventures. A Social Capital Approach and Research Agenda. Journal of Entrepreneurship and Innovation, 9(1), 33-42.

Blomqvist, K., Hurmelinna-Laukkanen, P., Nummela, N., \& Saarenketo, S. (2008). The Role of Trust and Contracts in the Internationalization of Technology-intensive Born Globals. Journal of Engineering Technology and Management, 25, 123-135.

Burgel, O., \&. Murray, G. C (2000). The International Market Entry Choices of Start-up Companies in High-Technology Industries. Journal of International Marketing, 8(2), 33-62.

Brüderl, J., \& Preisendörfer, P. (1998). Network support and the success of newly founded businesses. Small Business Economics, 10, 213-225.

Carmines, E. G., \& McIver, J. P. (1981). Analyzing Models with Unobserved Variables: Analysis of Covariance Structures. Social Measurement: Current Issues, 65-115.

Chen, T.-J. (2006). Liability of Foreignness and Entry Mode Choice: Taiwanese firms in Europe. Journal of Business Research, 59, $288-294$.

Claycomb, C., \& Frankwick, G.L. (2010). Buyers' Perspectives of Buyer-seller Relationship Development. Industrial Marketing Management, 39, 252-263.

Contractor, F. J. \& Lorange P. (1988). "Why should firms cooperate? The Strategy and Economics Basis for Co-operative Ventures" in Contractor, F.J. and P. Lorange (Eds.) Cooperative Strategies in International Business (pp.317-338). Lexington, MA: Lexington Books.

Cosset, J., \& Roy, J. (1991). The Determinants of Country Risk Ratings. Journal of International Business Studies, 22(1), 135-143.

Coviello, N.E., \& Jones, M.V. (2004). Methodological Issues in International Entrepreneurship Research. Journal of Business Venturing, 19(4), 485-508.

Coviello, N. E., \& Munro, H. J. (1995). Growing the entrepreneurial firm. Networking for international market development. European Journal of Marketing, 29(7), 49-61.

Coviello, N.E., \& Munro, H.J. (1997). Network Relationship and the Internationalisation Process of Small Software Firms. International Business Review, 6(4), 361-386. 
Crick, D., \& Jones, M. V. (2000). Small high-technology firms and international high-technology markets. Journal of International Marketing, 8(2), 63-85.

Crick, D., \& Spence, M. (2005). The internationalisation of 'high performing' UK high-tech SMEs: a study of planned and unplanned strategies. International Business Review, 14(2), 167-185.

Cunningham, M. T., \& Homse, E. (1986). Controlling the Marketing-purchasing Interface: Resource Development and Organisational Implications. Industrial Marketing and Purchasing, 1(2), 3-27.

Davenport, S., Davies, J., \& Grimes, C. (1999). Collaborative Research Programmes: Building Trust from Difference. Technovation, 19(1), 31-40.

Diamantopoulos, A., \& Winklhofer, H. (2001). Index Construction with Formative Indicators: An Alternative to Scale Development. Journal of Marketing Research, 38(2), 269-277.

Dyer, J. H., \& Singh, H. (1998). The Relational View: Cooperative Strategy and Sources of Interorganizational Competitive Advantage. Academy Management Review, 23(4), 660-679.

Eckhardt, J. T., \& Shane, S. A. (2003). Opportunities and entrepreneurship. Journal of management, 29(3), $333-349$.

Erramilli, M. K., \& Rao, C. P. (1993). Service Firms’ International Entry-Mode Choice: A Modified Transaction Cost Analysis Approach. Journal of Marketing, 57(July), 19-38.

Eurofound (2013). Born global: The Potential of Job Creation in New International Businesses. Eurofound, www.eurofound.europa.eu.

Fernhaber, S. A., \& McDougall, P. P. (2005). New Venture Growth in International Markets: The role of Strategic Adaptation and Networking Capabilities. In D.A. Shepherd \& J.A. Katz (Eds.), International Entrepreneurship (pp. 137-164). Oxford: Elsevier Ltd.

Fornell, C., \& Larker, D. F. (1981). Evaluating Structural Equation Models with Unobservable Variables and Measurement Error. Journal of Consumer Research, 18(1), 39-50.

Gabrielsson, M., Kirpalani, V. H. M., Dimistratos, P., Solberg, A. C., \& Zucchella, A. (2008). Born-global: Propositions to Help Advance the Theory. International Business Review, 17 (4), 385-401.

Galkina, T. \& Chetty, S. (2015). Effectuation and networking of internationalizing SMEs. Management International Review, 55(5): 647-676.

Gatignon, H., \& Anderson, E. (1988). The Multinational Corporation's Degree of Control over Foreign Subsidiaries: An Empirical Test of a Transaction Cost Explanation. Journal of Law, Economics and Organization, 4(2), 305 - 336. 
Gil-Pechuan, I., Exposito-Langa, M., \& Tomas-Miquel, J. V. (2013). International entrepreneurship in SMEs: a study of influencing factors in the textile industry. International Entrepreneurship and Management Journal, 9(1), 45-57.

Gleason, D.C., \& Wiggenhorn, J. (2007). Born globals, the choice of globalization strategy, and the market's perception of performance. Journal of World Business, 42(3), 322-335.

Grönroos, Ch. (2004). The relationship marketing process: communication, interaction, dialogue, value. Journal of Business \& Industrial Marketing, 19(2), $99-113$.

Grunert K. G., Fruensgaard, J. L., Risom, K., Sonne, A-M., Hansen, K., \& Trondsen, T. (2002). Market orientation at industry and value chain levels: concepts, determinants and consequences. Journal of Customer Behaviour, 1(2), 167194.

Gummesson, E., \& Mele, Ch. (2010). Marketing as Value Co-creation Through Network Interaction and Resource Integration. Journal of Business Market Management, 4(4), 181-198.

Hagen, B., \& Zucchella, A. (2014). Born Global or Born to Run? The Long-Term Growth of Born Global Firms. Management International Review, 54, 497-525.

Hair, J., Anderson, R., Tatham, R., \& Black, W. (1998). Multivariate Data Analysis. London: Prentice-Hall.

Hallén, L., Johanson, J., \& Seyed-Mohamed, N. (1991). Interfirm Adaptation in Business Relationships. Journal of Marketing, 55(2), 19-37.

Harrigan, K.R. (1988). Strategic alliance and partner asymmetries. Management International Review, 28(4), 53-72.

Hayduk, L. A. (1987). Structural Equation Modeling with LISREL. Baltimore: Johns Hopkins University Press.

Helfert, G., Ritter, T., \& Walter, A. (2002). Redefining Market Orientation from a Relationship Perspective. Theoretical Considerations and Empirical Results. European Journal of Marketing, 36(9/10), 1119-1139.

Hite, J. M., \& Hesterly, W. S. (2001). The Evolution of Firm Networks: From Emergence to Early Growth of the Firm. Strategic Management Journal, 22, 275-286.

Jansson, H., \& Sandberg, S. (2008). Internationalization of Small and Medium Sized Enterprises in the Baltic Sea Region. Journal of International Management, 14(1), 65-77.

Jantunen, A., Nummela, N., \& Saarenketo, S. (2008). Strategic Orientations of Born Globals - Do they Really Matter?. Journal of World Business, 43 (2), 158-170.

Jarvis, C. B, Mackenzie, S. B., \& Podsakoff, P. M. (2003). A Critical Review of Construct Indicators and Measurement Model Misspecification in Marketing and Consumer Research. Journal of Consumer Research, 30(2), 199-218. 
Johanson, J., \& Vahlne, J-E. (2009). The Uppsala Internationalization Process Model Revisited: From Liability of Foreignness to Liability of Outsidership. Academy of International Business, 40, 1411-1413.

Jones, M. V., \& Coviello, N. E. (2005). Internationalisation: conceptualising an entrepreneurial process of behaviour in time. Journal of International Business Studies, 36(3), 284-303.

Jones, M. V., Coviello, M., \& Tang, Y. K. (2011). Entrepreneurship Research (1989-2009): A Domain Ontology Analysis. Journal of Business Venturing, 26, 632-659.

Jöreskog, K. G., \& Sörbom, D. (1993). Lisrel 8: Structural Equation Modeling with the Simplis Command Language. Hilldale, N.J.: Lawrence Er lbaum Associates Publishers.

Kleinbaum, D. G., Kupper, L., \& Muller, K. E. (1988). Applied Regression Analysis and other Multivariable Methods. Boston: PWS-Kent.

Knight, G., \& Cavusgil, T. (2004). Innovation, Organizational Capabilities, and the born-global Firm. Journal of International Business Studies, 35, 124-141.

Kumar, V., \& Subramaniam, V. (1997). A contingency framework for the mode of entry decision. Journal of World Business, 32(1), 53-72.

Laurell, H., Achtenhagen, L., \& Andersson, S. (2015). The changing role of network ties and critical capabilities in an international new venture's early development. International Entrepreneurship and Management Journal, 1-28.

Löfgren, A., Tolstoy, D., Sharma, D. D., \& Johanson, J. (2008). Network Coordination as a Key to External Resources: A Study of an Internationalizing Biotech SME in L. P. Dana, I. M. Welpe, M., Han \& V. Ratten, (Eds.), Handbook of Research on European Business and Entrepreneurship (pp. 618-635). Cheltenham: Edward Elgar.

Lu J. W., \& Beamish, P. W. (2001). The Internationalization and Performance of SMEs. Strategic Management Journal, 22, 565-586.

MacCallum, R. C., \& Browne, M. W. (1993). The Use of Causal Indicators in Covariance Structure Models: Some Practical Issues. Psychological Bulletin, 114(3), 533-541.

Madhok, A. (1997). Cost, Value and Foreign Market Entry Mode: The Transaction and the Firm. Strategic Management Journal, 18 (1), 39-61.

Madhok A. (1998). The Nature of Multinational Firm Boundaries: Transaction Costs, Firm Capabilities, and Foreign Market Entry Modes. International Business Review, 7, 259-290. 
Madsen, T. K., \& Servais, P. (1997). The internationalization of Born Globals: An Evolutionary Process? International Business Review, 7, 561-583.

McDougall, P. P., \& Robinson, R. B. (1990). New Venture Strategies: An Empirical Identification of Eight Archetypes of Competitive Strategies for Entry. Strategic Management Journal, 11(6), 447-468.

McLoughlin, D., \& Horan, C. (2000). Business Marketing: Perspectives from the Markets-as-networks Approach. Industrial Marketing Management, 29(4), 285-292.

Melén, S., \& Rovira, E. (2009). The Internationalisation Modes of Born Globals: A Longitudinal Study. European Management Journal, 27, 243-254.

Milanov, H., \& Fernhaber, S. A. (2009). The Impact of Early Imprinting on the Evolution of New Venture networks. Journal of Business Venturing, 24(1), 46-61.

Mohr, J., \& Nevin, J. R. (1990). Communication Strategies in Marketing Channels. A Theoretical Perspective. Journal of Marketing, 54(4), 36-51.

Mohr, J., \& Spekman, R. (1994). Characteristics of Partnership Success: Partnership Attributes, Communication Behavior, and Conflict Resolution. Strategic Management Journal, 15(2), 135-152.

Ng, W., \& Rieple, A. (2014). Special issue on "The role of networks in entrepreneurial performance: new answers to old questions?" International Entrepreneurship and Management Journal, 10(3), 447-455.

Nummela, N., Saarenketo, S., Jokela, P. \& Loane, S. (2014). Strategic Decision-Making of a Born Global: A Comparative Study From Three Small Open Economies. Management International Review, 54,527-550.

Oakey, R., Rothwell, R., \& Cooper, S. (1988). The Management of Innovation in High-Technology Small Firms. London: Pinter Publishers.

Oviatt, B., \& McDougall, P. (1994). Toward a theory of International New Ventures, Journal of International Business Studies, 21 (1), 45-64.

Oviatt, B. M., \& McDougall, P. (2005). Defining International Entrepreneurship and Modelling the Speed of Internationalization. Entrepreneurship Theory and Practice, September, 1042-2587.

Pett, T. L., \& C. C. Dibrell (2001). A Process Model of Global Strategic Alliance Formation. Business Process Management Journal, 7 (4), 349-364.

Quinn, J. B., Mintzberg, H., \& James, R. M. (1988). The strategy process: concepts, contexts, and cases (Vol. 1). Prentice Hall. 
Rank, O.N. (2008). Formal structures and informal networks: Structural analysis in organizations, Scandinavian Journal of Management, 24(2), 145-16.

Rasheed, H. S. (2005). Foreign Entry Mode and Performance: The Moderating Effects of Environment. Journal of Small Business Management, 43, 1, 41-54.

Ripollés, M., Blesa, A. \& Monferrer, D. (2012). Factors Enhancing the Choice of Higher Resource Commitment Entry Modes in International New Ventures. International Business Review, 21(4), 648-666.

Ritter, T., \& Gemünden, H. G. (2003). Network competence: Its impact on innovation success and its antecedents. Journal of Business Research, 56(9), 745- 755.

Ritter, T., Wilkinson, I. F., \& Johnston, W. J. (2002). Measuring network competence: some international evidence. Journal of Business \& Industrial Marketing, 17(2/3), 119-138.

Ritter, T., Wilkinson, I. F., \& Johnston, W. J. (2004). Managing in complex business networks. Industrial marketing management, 33(3), 175-183.

Robinson, K. C., \& McDougall, P. (2001). Entry Barriers and New Venture Performance: A Comparison of Universal and Contingency Approaches. Strategic Management Journal, 22, 659-685.

Ruekert, R. W., \& O. C. Walker (1987). Marketing's Interaction with other Functional Units: a Conceptual Framework and Empirical Evidence. Journal of Marketing, 58(1), 1-19.

Sarasvathy, S. D. (2001). Causation and effectuation: toward a theoretical shift from economic inevitability to entrepreneurial contingency. Academy of Management Review, 26(2), 243-288.

Sarasvathy, S. \& Dew, N. (2003, January). Effectual networks: A pre-commitment approach to bridging the gap between opportunism and trust. InAOM meeting in Seattle. University of Maryland and University of Virginia.

Sarasvathy, S. D. \& Dew, N. (2005). New market creation through transformation. Journal of Evolutionary Economics, 15(5), 533-565.

Sarasvathy, S., Kumar, K., York, J. G., \& Bhagavatula, S. (2014). An effectual approach to international entrepreneurship: overlaps, challenges, and provocative possibilities. Entrepreneurship Theory \& Practice, 38(1), 71-93.

Sasi, V. \& Arenius, P. (2008). International new ventures and social networks: Advantage or liability? European Management Journal, 26(6): 400-411.

Schlosser F. K., \& McNaughton, R. B. (2009). Individual-level Antecedents to Market-oriented Actions. Journal of Business Research, 60 (5), 438-446. 
Solis-Rodriguez, V., \& Gonzalez-Diaz, M. (2012). How to design franchise contracts: The role of contractual hazards and experience. Journal of Small Business Management, 50(4), 652-677.

Tabachnick, B. G. \& Fidell, L. S. (2007). Using Multivariate Statistics (5th ed.). New York: Allyn and Bacon.

Teece, D. J., Pisano, G., \& Shuen, A. (1997). Dynamic Capabilities and Strategic Management. Strategic Management Journal, 18 (7), 509-533.

Wheaton, B. (1987). Assessment of Fit in Overidentified Models with Latent Variables. Sociological Methods and Research, 16, 118-154.

Wheaton, B., Muthen, B., Alwin, D.F., \& Summers, G. (1977). Assessing Reliability and Stability in Panel Models. Sociological Methodology, 8(1), 84-136.

Williamson, O. E. (1985). The Economic Institutions of Capitalism. New York: The Free Press.

Wood, E., Khavul, S., Perez-Nordtvedt, L., Prakhya, S., Dabrowski, R. V. \& Zheng, C. (2011). Strategic Commitment and Timing of Internationalization from Emerging Markets: Evidence from China, India, Mexico, and South Africa. Journal of Small Business Management, 49 (2), 252-282.

Zacharakis, A. (1997). Entrepreneurial Entry into Foreign Markets: A Transaction Cost Perspective. Entrepreneurship Theory and Practice, 21(3), 23-40. 
Descriptive characteristics of the sample

\begin{tabular}{|c|c|c|}
\hline Economic sector & Age & Employees \\
\hline Agriculture, forestry and fishing $=6 \%$ & & \\
Manufacturing $=44.5 \%$ & 1 year $=0.5 \%$ & $3-15=61.5 \%$ \\
Electric power supply $=3 \%$ & 2 years $=14.5 \%$ & $16-55=25 \%$ \\
Wholesale and retailing $=39 \%$ & 3 years $=32.5 \%$ & $58-208=13.5 \%$ \\
Professional, scientific and technical activities $=3 \%$ & 4 years $=52.5 \%$ & \\
Others $=4.5 \%$ & & \\
\hline
\end{tabular}

\begin{tabular}{|c|c|c|c|c|}
\hline \multicolumn{5}{|c|}{ International activities } \\
\hline $\begin{array}{c}\text { International } \\
\text { production }\end{array}$ & $\begin{array}{c}\text { International } \\
\mathbf{R}+\mathbf{D}\end{array}$ & Marketing & $\begin{array}{c}\text { Advertising and } \\
\text { promotion }\end{array}$ & $\begin{array}{c}\text { Customer } \\
\text { service }\end{array}$ \\
\hline $25 \%-50 \%=88.5 \%$ & $25 \%-50 \%=94.5 \%$ & $25 \%-50 \%=71.7 \%$ & $25 \%-50 \%=93.9 \%$ & $25 \%-50 \%=88.9 \%$ \\
$51 \%-75 \%=2 \%$ & $51 \%-75 \%=1 \%$ & $51 \%-75 \%=13.7 \%$ & $51 \%-75 \%=1.6 \%$ & $51 \%-75 \%=4.5 \%$ \\
$75 \%-100 \%=9.5 \%$ & $75 \%-100 \%=4.5 \%$ & $75 \%-100 \%=14.6 \%$ & $75 \%-100 \%=4.5 \%$ & $75 \%-100 \%=6.6 \%$ \\
\hline
\end{tabular}

\section{Table 2.}

Inter-firm network management activities scale

\section{Inter-firm knowledge sharing}

We develop conjoint learning on market demands (KONWSHA1)

We exchange information to react immediately to new market demands (KONWSHA2)

We exchange knowledge to improve our offerings (KONWSHA3)

We jointly develop solutions for new market demands (KONWSHA4)

\section{Coordination}

We discuss in collaboration who is doing what in an inter-firm context (COORDIN1)

We ensure that promises on all sides are fulfilled (COORDIN2)

We discuss the steps for fulfilling the aims of the relationships (COORDIN3)

\section{Conflict}

We try hard to protect our firm's interest in case of conflicts (CONFLIC1) [Reverse scored]

We wait a considerable time in case of conflicts as a cooling-off period (CONFLIC2) [Reverse scored]

We try to establish a compromise which is acceptable for all sides when a conflict arises (CONFLIC3)

\section{Adaptation}

We adapt offerings to market demands conjointly (ADAPTAT1)

We adapt delivery and usage of our offerings conjointly (ADAPTAT2)

\section{Resource availability}

Inter-firm network members have access to technical systems and equipment from other members (RESOURC1). Inter-firm network members have access to information about customers from other members (RESOURC2). Inter-firm network members have access to market information from other members (RESOURC3). Inter-firm network members have access to information about other members' strategic aims (RESOURC4). 
Inter-firm network members have time which can be used to maintain relationships with other firms (RESOURC5).

Table 3.

External validity of indexes.

\begin{tabular}{|c|c|c|}
\hline Scale & NEEMs & EEMs \\
\hline Reflective indicators & $\begin{array}{c}\text { 1. Satisfaction with the access to the market. } \\
\text { 2. Satisfaction with international performance. }\end{array}$ & $\begin{array}{c}\text { 1. Satisfaction with the access to the market. } \\
\text { 2. Satisfaction with international } \\
\text { performance. }\end{array}$ \\
\hline$\chi^{\mathbf{2} / \mathbf{f d}}$ & 1.09 & 1.16 \\
\hline RMSR & 0.15 & 0.03 \\
\hline GFI & 0.90 & 1.00 \\
\hline NFI & 0.82 & 0.99 \\
\hline CFI & 0.96 & 1.00 \\
\hline IFI & 0.96 & 1.00 \\
\hline
\end{tabular}

Table 4.

Discriminant validity tests

\begin{tabular}{|c|c|c|c|c|}
\hline \multicolumn{5}{|c|}{ Confidence interval test } \\
\hline \multicolumn{3}{|c|}{ Scales } & Correlation & Confidence interval \\
\hline \multicolumn{3}{|c|}{ Inter-firm network management activities - EEMs } & 0.10 & {$[-0.17 ; 0.39]$} \\
\hline \multicolumn{3}{|c|}{ Inter-firm network management activities - NEEMs } & -0.036 & {$[-0.27 ; 0.20]$} \\
\hline \multicolumn{3}{|c|}{ EEMs - NEEMs } & 0.74 & {$[0.60 ; 0.88]$} \\
\hline \multicolumn{3}{|c|}{ Inter-firm network management activities - International Performance } & 0.33 & {$[0.09 ; 0.57]$} \\
\hline \multicolumn{3}{|c|}{ NEEMs- International Performance } & -0.01 & {$[-0.928 ; 0.928]$} \\
\hline \multicolumn{5}{|c|}{ Extracted variance test } \\
\hline Scales & EV & \multicolumn{3}{|c|}{ Squares correlation between constructs } \\
\hline $\begin{array}{l}\text { Inter-firm network } \\
\text { management activities }\end{array}$ & 0.688 & \multirow{3}{*}{\multicolumn{3}{|c|}{$\begin{array}{l}\text { Inter-firm network management activities }-\mathrm{NEEM}=0.001 \\
\text { Inter-firm network management activities }- \text { International Performance }=0.109 \\
\text { NEEMs- International Performance }=0.000\end{array}$}} \\
\hline NEEMs & 0.513 & & & \\
\hline International Performance & 0.604 & & & \\
\hline
\end{tabular}

\section{Table 5.}

Descriptive statistics and correlations

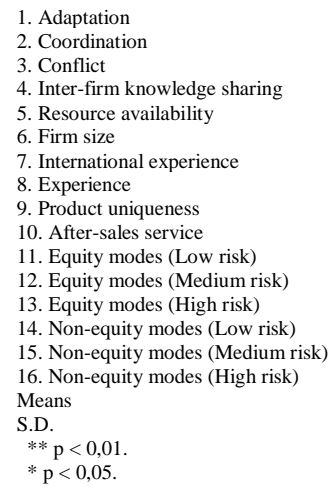

Table 6. 
Results of standardized parameters estimation for the model of the influence of inter-firm network management activities on NEEMs

\begin{tabular}{|c|c|c|c|c|c|c|}
\hline \multicolumn{4}{|c|}{ Relation } & Parameter & \multicolumn{2}{|c|}{$t$ (Significance) } \\
\hline \multicolumn{4}{|c|}{ After-sales services - EEMs } & 0.04 & \multicolumn{2}{|c|}{1.68} \\
\hline \multicolumn{4}{|c|}{ After-sales services - NEEMs } & 0.05 & \multicolumn{2}{|c|}{1.25} \\
\hline \multicolumn{4}{|c|}{ Product uniqueness - EEMs } & 0.05 & \multicolumn{2}{|c|}{$2.86(p<0.01)$} \\
\hline \multicolumn{4}{|c|}{ Product uniqueness - NEEMs } & -0.07 & \multicolumn{2}{|c|}{-1.82} \\
\hline \multicolumn{4}{|c|}{ NMA - NEEMs } & 0.73 & \multicolumn{2}{|c|}{$9.21(\mathrm{p}<0.001)$} \\
\hline \multicolumn{4}{|c|}{ NMA - EEMs } & -0.76 & \multicolumn{2}{|c|}{$-8.88(\mathrm{p}<0.001)$} \\
\hline \multicolumn{4}{|c|}{ Control variables } & Parameter & \multicolumn{2}{|c|}{$t$ (Significance) } \\
\hline \multicolumn{4}{|c|}{ Firm size - EEMs } & -0.11 & \multicolumn{2}{|c|}{$-4.46(\mathrm{p}<0.001)$} \\
\hline \multicolumn{4}{|c|}{ Firm size - NEEMs } & 0.21 & \multicolumn{2}{|c|}{$3.51(\mathrm{p}<0.001)$} \\
\hline \multicolumn{4}{|c|}{ International experience - EEMs } & -0.21 & \multicolumn{2}{|c|}{$-3.30(\mathrm{p}<0.001)$} \\
\hline \multicolumn{4}{|c|}{ International experience - NEEMs } & -0.01 & \multicolumn{2}{|c|}{-0.12} \\
\hline \multicolumn{4}{|c|}{ Experience - EEMs } & 0.20 & \multicolumn{2}{|c|}{$3.76(\mathrm{p}<0.001)$} \\
\hline \multicolumn{4}{|c|}{ Experience - NEEMs } & -0.10 & \multicolumn{2}{|c|}{-1.49} \\
\hline \multicolumn{7}{|c|}{ Measurements of quality of fit } \\
\hline $\mathrm{X}^{2} / \mathrm{fd}=1.86$ & $\mathrm{RMSR}=0.047$ & GFI $=0.95$ & $\mathrm{NFI}=0.97$ & $\mathrm{CFI}=0.99$ & $\mathrm{IFI}=0.99$ & $\mathrm{RFI}=0.94$ \\
\hline
\end{tabular}

